\title{
Penerapan Strategi Kesopanan Berbahasa di WhatsApp Group Kelas 5 SDN Sumberbening 1 Kabupaten Ngawi Pada Masa Pandemi Covid-19
}

Yetik Mayasari $\bowtie$, Universitas PGRI Madiun

V. Teguh Suharto, Universitas PGRI Madiun

Sigit Ricahyono, Universitas PGRI Madiun

Yetikmayasari10@gmail.com

\begin{abstract}
Abstrak: Pada masa pandemi komunikasi dilakukan menggunakan media sosial karena pembelajaran dilakukan secara online. Meskipun melalui media sosial diharapkan kesopanan dalam berkomunikasi bisa diterapkan dengan baik. Oleh sebab itu dalam Penelitian ini bertujuan untuk memperoleh deskripsi yang jelas tentang Penerapan Strategi Kesopanan Berbahasa di WhatsApp Group Kelas 5 SDN Sumberbening 1 Kabupaten Ngawi pada Masa Pandemi Covid-19. Metode penelitian yang digunakan adalah deskriptif kualitatif. Sumber data yang digunakan adalah dokumen. Peristiwa dalam penelitian ini adalah segala bentuk komunikasi di group chat WhatsApp antara murid dan guru, wali murid dan guru, murid dan murid. Dokumen penelitian ini adalah tangkapan layar WhatsApp. Teknik pengumpulan data pada penelitian ini menggunakan dokumentasi. Teknik analisis data menggunakan persentase dan deskriptif. Hasil penelitian ini menunjukkan bahwa strategi kesopanan dalam pembelajaran masih dilakukan dengan baik yang berarti strategi kesopanan sesuai dengan taxonomi Scollon dan Scollon.
\end{abstract}

Kata Kunci : Kesopanan berbahasa, Strategi kesopanan berbahasa, Group chat WhatApps

Abstract: Because learning was done online throughout the epidemic, communication was done through social media. Although it is believed that courtesy in communication can be appropriately implemented through social media. As a result, the goal of this research is to have a clear picture of how Politeness Strategies were used in WhatsApp Group Class 5 SDN Sumberbening 1 Ngawi Regency during the Covid-19 Pandemic. The descriptive qualitative research approach along with tallies was applied. Data were collected from messages by WhatsApp Group Members between students and instructors, parents and teachers, and students and students are included in this study. Screenshots of WhatsApp were used in this study document. The results of this study indicate that the politeness strategies as available in Scollon and Scollon Taxonomy were well implemented in the learning context communication.

Keywords: politeness of language, politeness strategy, WhatApps group chat

Citation: Mayasari, Y., Suharto, V.T., \& Ricahyono, S. (2022). Penerapan Strategi Kesopanan Berbahasa di WhatsApp Group Kelas 5 SDN Sumberbening 1 Kabupaten Ngawi Pada Masa Pandemi Covid-19. Wewarah: Jurnal Pendidikan Multidisipliner, 1(1), 80 - 96.

(cc) Br

Published by Program Pascasarjana Universitas PGRI Madiun. This work is licensed under the Creative Commons Attribution-

NonCommercial-ShareAlike 4.0 International License. 


\section{PENDAHULUAN}

Manusia sebagai makhluk sosial tidak bisa lepas dari hubungan, kepentingan, atau bantuan manusia lainnya, dan semua aktivitas itu membutuhkan komunikasi di dalamnya. Karena komunikasi, seperti halnya kebutuhan akan relasi dengan manusia lainnya, merupakan kebutuhan dasar yang hampir setiap orang merasakannya. Tidak ada satu manusiapun yang tidak membutuhkan komunikasi. Ia merupakan penghubung maksud dari kehendak manusia lain, sehingga tercipta relasi yang di maksud, baik itu di dalam kehidupan sehari-hari di rumah tangga, di tempat kerja, di pasar, di sekolah, di perpustakaan, bahkan di dalam berbangsa dan bernegara. Sifat manusia untuk menyampaikan keinginannya dan untuk mengetahui hasrat orang lain, merupakan awal keterampilan manusia berkomunikasi secara otomatis melalui lambang isyarat, kemudian disusul dengan kemampuan untuk memberi arti setiap lambang itu dalam bentuk bahasa verbal. Mengapa manusia ingin selalu membangun komunikasi dengan manusia lainnya? Berdasarkan teori dasar Biologi menyebutkan dalam kehidupan manusia terdapat dua kebutuhan, yakni kebutuhan untuk mempertahankan kelangsungan hidupnya dan kebutuhan untuk menyesuaikan diri dengan lingkungannya. Dengan adanya komunikasi maka terjadilah juga hubungan sosial. Karena manusia itu adalah sebagai makhluk sosial, maka terjadilah interaksi timbal balik. Orang yang masih hidup tidaklah mungkin akan terlepas dari komunikasi, walaupun bukan berarti semua perilaku adalah komunikasi. Komunikasi terjadi dalam hampir setiap kegiatan manusia. Untuk lebih tegas dapat dikatakan bahwa banyak kegiatan manusia yang hanya bisa terjadi dengan bantuan komunikasi. Komunikasi adalah proses penyampaian atau penerimaan pesan dari satu orang kepada orang lain, baik langsung maupun tidak langsung, secara tertulis, lisan, maupun bahasa nonverbal. Komunikasi dalam pendidikan merupakan unsur yang sangat penting kedudukannya, bahkan ia sangat besar peranannya dalam menentukan keberhasilan pendidikan yang bersangkutan. Orang sering berkata bahwa tinggi rendahnya suatu pencapaian mutu pendidikan dipengaruhi oleh faktor komunikasi ini, khususnya komunikasi pendidikan. Di dalam pelaksanaan pendidikan formal (pendidikan sekolah), tampak jelas adanya peran komunikasi yang sangat menonjol. Proses belajar mengajarnya sebagian besar terjadi karena proses komunikasi, baik komunikasi yang berlangsung secara intra personal maupun secara antar personal. Oleh karena itu, penting bagi kita menjadi terampil berkomunikasi, dan mengetahui prinsip-prinsip komunikasi baik di dalam pendidikan maupun masyarakat. Oleh karena itu dalam berkomunikasi harus memakai etika yang benar. Etika komunikasi dikaitkan dengan watak atau kesusilaan yang menentukan benar atau tidaknya cara penyampaian pesan kepada orang lain yang dapat mengubah sikap, pendapat, atau perilaku baik secara lisan ataupun tidak langsung. Etika komunikasi adalah norma, nilai, atau ukuran tingkah laku yang baik dalam kegiatan komunikasi dengan orang lain.

Etika komunikasi perlu diperhatikan agar tidak terjadi suatu prasangka buruk yang dapat mengakibatkan dampak negatif terhadap orang lain. Contohnya, setiap siswa tidak boleh mengeluarkan kata-kata yang kurang enak didengar yang bisa membuat perasaan orang lain menjadi tersinggung. Dengan demikian etika komunikasi memegang peranan penting dalam pendidikan.

Ada beberapa hal pokok yang mana kita selaku komunikator perlu lakukan dan perlu aplikasikan dalam kehidupan, antara lain fokus pada lawan bicara, fokus pada masalah, jangan menimpali/menyela pembicaraan, saling menghargai, dan selingi dengan humor.

Dalam berkomunikasi ada juga etika tersendiri yang harus kita pegang, kita selaku individu perlu menjaga perasaan lawan bicara kita agar mereka tidak tersinggung ataupun salah paham dengan maksud dan tujuan kita. Sedangkan berikut hal-hal yang perlu dihindari dalam Etika Berkomunikasi dengan orang lain adalah penggunaan kalimat informal (tidak baku), berbicara sambil melakukan hal lain, terlalu banyak basa-basi, berbicara dengan nada kasar, nada memerintah, tidak boleh menghakimi, dan manage intonasi.

Seperti yang disampaikan diatas tadi, komunikasi dapat dilakukan secara langsung dan tidak langsung. Komunikasi langsung terjadi ketika sang komunikator dan komunikan saling bertatap muka sehingga tanpa dibutuhkan perantara media sedangkan komunikasi tidak langsung terjadi ketika komunikator berkomunikasi dengan membutuhkan bantuan berupa media perantara yang bertujuan sebagai penghantar pesan agar informasi bisa sampai kepada sang komunikan. Komunikasi langsung ditemui ketika sedang berbicara langsung dengan lawan bicara ketika itu juga. Komunikasi tidak langsung ditemui ketika komunikasi menggunakan perantara seperti melalui surat, email, telepon, dan 
media massa atau media sosial.

Pada masa pandemi ini mulai tahun 2020 pembelajaran di sekolah dituntut melalui daring. Komunikasi dalam pembelajaran antara guru dan murid dilakukan secara tidak langsung. Komunikasi dilakukan melalui media sosial. Media sosial merupakan suatu wadah sebagai sarana pertemuan atau pergaulan sosial secara online melalui internet atau dunia maya. Melalui media sosial komunikasi secara tidak langsung menjadi lebih mudah dan efisien. Pengguna media sosial mampu saling berkomunikasi, berinteraksi, berbagi, serta melakukan berbagai kegiatan lainnya.

Dewasa ini media sosial menjadi aplikasi paling populer dikalangan warganet di Indonesia. Trend penggunanya terus naik secara signifikan, begitu pula dengan fitur-fitur yang dapat dinikmati secara gratis oleh penggunanya juga semakin berkembang. Menurut riset yang digarap We are sosial Hootsuite yang dirilis Januari 2019 pengguna media sosial di Indonesia mencapai 150 juta atau sebesar $56 \%$ dari total populasi. Jumlah tersebut naik $20 \%$ dari survei yang sebelumnya.

Situs jejaring media sosial hadir menjadi sesuatu yang digemari oleh masyarakat banyak. Salah satunya ialah WhattsApp. WhatsApp menjadi aplikasi chat paling populer saat ini. Aplikasi ini kabarnya digunakan oleh 1,5 miliar pengguna diseluruh dunia. Bahkan menurut laporan Sensor Tower, WhatsApp menjadi aplikasi yang paling banyak diunduh di Play Store dan App Store selama 2019. Di dalam aplikasi WhattsApp terdapat Group Chat WhattsApp. Grupchat WhatsApp adalah fitur yang dapat digunakan untuk berkomunikasi dengan beberapa kontak teman yang ada di WhatsApp. Adanya Group chat WhatsApp ini memudahkan pengirim pesan dalam menyebarkan informasi dimana pesan atau informasi dapat diterima oleh penerima pesan dalam waktu yang bersamaan.

Meskipun terjadi komunikasi secara tidak langsung, berkomunikasi dengan Group chat WhattsApp harus menggunakan bahasa yang sopan. Sopan santun akan selalu diperlukan di dalam setiap komunikasi. Hal ini dikarenakan sopan santun merupakan unsur penting dalam kehidupan bersosialisasi dan komunikasi di dalam kehidupan sehari-hari. Dengan menunjukan sikap yang santun, seseorang menjadi dihargai dan disenangi keberadaannya sebagai makhluk sosial dimanapun mereka berada. Syarat sopan santun antara lain adalah menggunakan bahasa yang baik, tidak menggunakan nada tinggi terhadap orang tua, dan menghargai pendapat orang lain.

Sopan santun sudah menjadi bagian dari bentuk kepribadian setiap manusia. Kadar sopan santun pada tiap manusia adalah berbeda satu sama lain tergantung kondisi sosial manusia itu sendiri. Meski begitu kenyataannya sampai dewasa ini masih banyak ditemukan pelanggaran yang terjadi di dalam lingkungan pendidikan. Contoh pelanggaran itu misalnya memotong pembicaraan guru, memaksakan kehendak pribadi, dan mencaci teman. Pengetahuan tentang sopan santun yang didapatkan disekolah mungkin telah cukup didapatkan. Tetapi karena siswa lebih banyak waktu di luar sekolah sehingga mudah terpengaruh dengan lingkungan luar.

Pada kajian pragmatik terdapat suatu strategi yang mengatur tentang bagaimana seorang manusia bertutur kata di dalam situasi tertentu. Salah satunya ialah strategi kesopanan. Dengan mengetahui strategi kesopanan kita sebagai penutur dapat menerapkan atau mengimplementasikannya dalam situasi atau konteks tertentu ketika membuat tuturan. Kesopansantunan pada umumnya berhubungan dengan dua partisipan yang disebut sebagai 'diri sendiri' dan 'orang lain'. Peserta percakapan dituntut untuk tidak menyimpang atau melanggar dari kaidah kebahasaan. Strategi kesopanan harus diperhatikan oleh setiap peserta percakapan ketika sedang berkomunikasi supaya tidak menimbulkan perkataan yang tidak sopan atau menyakiti perasaan orang lain. Apabila terdapat percakapan yang tidak sesuai dengan aturan strategi kesopanan maka percakapan tersebut termasuk dalam bentuk pelanggaran dari strategi kesopanan.

Berdasarkan latar belakang yang telah dipaparkan tersebut di atas, penulis melakukan penelitian yang berjudul "Penerapan Strategi Kesopanan Berbahasa di WhatsApp Group Kelas 5 SDN Sumberbening 1,Kabupaten Ngawi pada Masa Pandemi Covid-19".

\section{METODE}

\section{Pendekatan dan Jenis Penelitian}

Penelitian ini menggunakan pendekatan kualitatif yang bersifat deskriptif. Pemilihan jenis penelitian ini sesuai dengan tujuan penelitian yang ingin menganalisis dan mendeskripsikan penerapan kesopanan 
berbahasa dalam komunikasi pembelajaran di WhatsApp group kelas 5 .

\section{Tempat dan Waktu Penelitian}

Penelitian Strategi Kesopanan berbahasa di WhatsApp Group dilaksanakan di Kelas 5 SDN Sumberbening 1, Kabupaten Ngawi pada Masa Pandemi Covid-19, pelaksanaannya kurang lebih selama 5 bulan yakni mulai bulan Februari hingga bulan Juni 2021.

\section{Subjek Penelitian}

Subjek penelitian ini yaitu komunikasi murid dan guru, wali murid dan guru, murid dan murid Kelas 5 SDN Sumberbening 1 Kabupaten Ngawi pada Masa Pandemi Covid-19.

\section{Prosedur Penelitian}

Prosedur penelitian ini mulai dari menyusun data, klasifikasi data, analisis, dan laporan.

\section{Instrumen pengumpulan Data}

Peneliti menggunakan instrumen utama dokumentasi skrinsoot WhatsApp yang setelah terkumpul diklasifikasikan dan di tabulasi dalam tabel analisis data.

\section{Analisis data}

Analisis dilakukan terhadap isi komunikasi dalam pembelajaran daring melalui WhatsApp Group. Langkah-langkah yang dilakukan ialah peneliti melakukan pengelompokan terhadap data yang akan dijadikan unit amatan penelitian. Data dikelompokkan berdasarkan jenis komunikasi antara murid dan guru, wali murid dan guru, murid dan murid. Lalu dianalisis dengan menggunakan alat kerja tabel analisis data. Dalam penelitian ini, peneliti ingin mengetahui bagaimana tentang strategi kesopanan berbahasa yang terdapat dalam komunikasi pembelajaran daring melalui WhatsApp Group. Dalam menganalisis data, peneliti membaca lalu mencatat komunikasi pembelajaran daring melalui WhatsApp Group sesuai dengan sistem dan strategi kesopanan menurut Scollon dan Scollon (2001). Selanjutnya dari pengelompokan tersebut dianalisis apakah komunikasi tersebut masuk kedalam penerapan dari strategi kesopanan berbahasa.

\section{HASIL PENELITIAN}

Pada hakikatnya aturan prinsip kesopanan dibuat supaya masyarakat dapat bertutur kata secara sopan dan dapat menghindari tutur kata yang tidak sopan. Hal ini diharapkan supaya tidak ada diantara penutur ataupun lawan tutur yang tersinggung atau mendapat kesalahpahaman ketika sedang melakukan kegiatan komunikasi secara langsung maupun tidak langsung. Pada penelitian ini akan membahas strategi kesopanan berbahasa di WhatsApp Group Kelas 5 SDN Sumberbening 1, Kabupaten Ngawi pada Masa Pandemi Covid-19 Tahun Pelajaran 2020/2021. Fungsi dari analisis ini ialah untuk mengetahui penerapan yang terjadi dalam komunikasi percakapan pada WhatsApp group kelas 5 . Pengumpulan data penelitian ini dilaksanakan pada bulan Februari sampai Juni tahun 2021. Data yang diperoleh berasal dari skrinshot WhatsApp Group kelas 5. Pada data tersebut nantinya akan dianalisis beberapa data yang merupakan penerapan ataupun pelanggaran.

Berdasarkan rumusan masalah dalam penelitian ini, berikut hasil penelitian yang akan dibahas: Bagaimanakah penerapan strategi kesopanan berbahasa di WhatsApp Group Kelas 5 SDN Sumberbening 1, Kabupaten Ngawi pada Masa Pandemi Covid-19 Tahun Pelajaran 2020/2021"?.

Berdasarkan data yang diperoleh di lapangan ditemukan bentuk kesopanan berbahasa dalam komunikasi di WhatsApp group antara murid dan guru, wali murid dan guru serta murid dan murid. 
Tabel 1 : Ringkasan analisis percakapan murid dan guru

\begin{tabular}{|c|c|c|c|c|c|c|c|c|c|}
\hline \multirow{2}{*}{ No. } & \multirow{2}{*}{$\begin{array}{c}\text { Percak } \\
\text { apan }\end{array}$} & \multicolumn{7}{|c|}{ Sistem } & \multicolumn{2}{c|}{ Strategi } & \multicolumn{2}{c|}{ Kesesuaian } \\
\cline { 3 - 10 } & & DEF & SOL & HID & HIU & INV & IND & Sesuai & Tidak \\
\hline 1 & 1 & 14 & & 11 & 3 & 10 & 4 & 13 & 1 \\
\hline 2 & 2 & 12 & & 6 & 6 & 9 & 3 & 9 & 3 \\
\hline 3 & 3 & 5 & & 1 & 4 & 5 & & 1 & 4 \\
\hline 4 & 4 & 6 & & 2 & 4 & 5 & 1 & 3 & 3 \\
\hline 5 & 5 & 9 & & 4 & 5 & 6 & 3 & 6 & 3 \\
\hline 6 & 6 & 10 & & 5 & 5 & 10 & & 5 & 5 \\
\hline & Jumlah & $\mathbf{5 6}$ & & $\mathbf{2 9}$ & $\mathbf{2 7}$ & $\mathbf{4 5}$ & $\mathbf{1 1}$ & $\mathbf{3 7}$ & $\mathbf{1 9}$ \\
\hline & $\mathbf{\%}$ & $\mathbf{1 0 0}$ & $\mathbf{\%}$ & $\begin{array}{c}\mathbf{5 1 , 8} \\
\mathbf{\%}\end{array}$ & $\mathbf{4 8 , 2}$ & $\begin{array}{c}\mathbf{8 0 , 3} \\
\mathbf{\%}\end{array}$ & $\begin{array}{c}\mathbf{1 9 , 7} \\
\mathbf{\%}\end{array}$ & $\mathbf{6 6 , 1} \%$ & $\mathbf{3 3 , 9} \%$ \\
\hline
\end{tabular}

Dari tabel 1 diperoleh data percakapan murid dan guru yang menerapkan sistem dan strategi kesopanan model Scollon dan Scollon sebanyak 37 data atau 66,1\%.

Tabel 2: Analisis kesopanan percakapan murid dan guru

\begin{tabular}{|l|l|l|c|c|c|c|c|c|c|c|}
\hline No. & Kode & \multicolumn{1}{|c|}{ Data } & \multicolumn{3}{|c|}{ Sistem } & \multicolumn{2}{c|}{ Strategi } & \multicolumn{2}{c|}{ Kesesuaian } \\
\cline { 3 - 11 } & & DEF & SOL & HID & HIU & INV & IND & Sesuai & Tidak \\
\hline 1 & P1. Begini ee Bu saya & $\sqrt{ }$ & & & $\sqrt{ }$ & $\sqrt{ }$ & & & $\sqrt{ }$ \\
ulangi & $\begin{array}{c}\text { 02. Kenapa sih Bu } \\
\text { enggak di classroom } \\
\text { aja }\end{array}$ & $\sqrt{ }$ & & & $\sqrt{ }$ & $\sqrt{ }$ & & & $\sqrt{ }$ \\
\hline $\mathbf{3}$ & P2 & 01. Klik oke & $\sqrt{ }$ & & $\sqrt{ }$ & & $\sqrt{ }$ & & $\sqrt{ }$ & \\
\hline 4 & P3 & $\begin{array}{l}\text { 01. Ea bu di classroom } \\
\text { aja bu }\end{array}$ & $\sqrt{ }$ & & & $\sqrt{ }$ & $\sqrt{ }$ & & & $\sqrt{ }$ \\
\hline $\mathbf{5}$ & P1 & $\begin{array}{l}\text { 03. Sudah saya klik bu } \\
\text { tapi juga enggak } \\
\text { bisa }\end{array}$ & $\sqrt{ }$ & & & $\sqrt{ }$ & $\sqrt{ }$ & & & $\sqrt{ }$ \\
\hline & Jumlah & $\mathbf{5}$ & $\mathbf{5}$ & $\mathbf{1}$ & $\mathbf{4}$ & $\mathbf{5}$ & & $\mathbf{1}$ & $\mathbf{4}$ \\
\hline
\end{tabular}

\section{Keterangan:}

- Dialog terjadi pada waktu pagi, antara pukul 07.55 sampai 07.56

- Pihak yang terlibat dalam percakapan adalah :

$\mathrm{P} 1=$ Anak, perempuan, murid

$\mathrm{P} 2=\mathrm{Ibu}$, perempuan, guru

P3 = Anak, laki-laki, murid

- Topik Pembicaraan : Tidak bisa membuka SIMPEL

- Nada percakapan : santai dan serius

Contoh data percakapan guru ke murid yang menerapkan sistem dan strategi kesopanan model Scollon dan Scollon pada tabel 4.4 ialah :

$P 2$ : 01. Klik oke

Dari contoh data tersebut, sistem masuk dalam Deference (D+) dan Hierarchy HL (HDw). Dinilai dari Hierarchy HL (H-Dw) komunikasi antara guru ke murid, dari segi usia tinggi ke rendah sehingga menggunakan strategi kesopanan Involvement. Sehingga percakapan yang dilakukan guru tersebut sesuai dengan sistem dan strategi kesopanan Model Scollon dan Scollon. 
Tabel 3 : Analisis kesopanan percakapan murid dan guru

\begin{tabular}{|l|l|l|c|c|c|c|c|c|c|c|}
\hline No. & \multirow{2}{*}{ Kode } & \multicolumn{3}{|c|}{ Data } & \multicolumn{3}{c|}{ Sistem } & \multicolumn{2}{c|}{ Strategi } & \multicolumn{2}{c|}{ Kesesuaian } \\
\hline & & DEF & SOL & HID & HIU & INV & IND & Sesuai & Tidak \\
\hline 1 & P1 & $\begin{array}{c}\text { 01. Bu yang nomer 7 } \\
\text { kok gk ada soalnya } \\
\text { bu? }\end{array}$ & $\sqrt{ }$ & & & $\sqrt{ }$ & $\sqrt{ }$ & & & $\sqrt{ }$ \\
\hline 2 & P2 & 01. AKM ato apa? & $\sqrt{ }$ & & $\sqrt{ }$ & & $\sqrt{ }$ & & $\sqrt{ }$ & \\
\hline 3 & P1 & 02. AKM bu & $\sqrt{ }$ & & & $\sqrt{ }$ & & $\sqrt{ }$ & $\sqrt{ }$ & \\
\hline 4 & P2 & $\begin{array}{c}\text { 02. Soalnya } \\
\text { ada..halaman 102. }\end{array}$ & $\sqrt{ }$ & & $\sqrt{ }$ & & $\sqrt{ }$ & & $\sqrt{ }$ & \\
\hline 5 & P1 & 03. Tidak ada ee bu & $\sqrt{ }$ & & & $\sqrt{ }$ & $\sqrt{ }$ & & & $\sqrt{ }$ \\
\hline 6 & & $\begin{array}{c}\text { 04. Adanya bacaan } \\
\text { PESAWAT } \\
\text { TEMPURee bu }\end{array}$ & $\sqrt{ }$ & & & $\sqrt{ }$ & $\sqrt{ }$ & & & $\sqrt{ }$ \\
\hline & & Jumlah & $\mathbf{6}$ & & $\mathbf{2}$ & $\mathbf{4}$ & $\mathbf{5}$ & $\mathbf{1}$ & $\mathbf{3}$ & $\mathbf{3}$ \\
\hline
\end{tabular}

\section{Keterangan:}

- Dialog terjadi pada waktu sore, antara pukul 18.34 sampai 19.09

- Pihak yang terlibat dalam percakapan adalah :

$\mathrm{P} 1$ = Anak, perempuan, murid

$\mathrm{P} 2$ = Ibu, perempuan, guru

- Topik Pembicaraan : Membahas soal AKM

- Nada percakapan : santai dan serius

Contoh data percakapan murid ke guru yang menerapkan sistem dan strategi kesopanan model Scollon dan Scollon pada tabel 4.5 ialah :

$P 1: 02 . A K M b u$

Dari contoh data tersebut, sistem masuk dalam Deference (D+) dan Hierarchy LH (HUp). Dinilai dari Hierarchy LH (H-Up) komunikasi antara murid ke guru, dari segi usia rendah ke tinggi sehingga menggunakan strategi kesopanan Independence. Sehingga percakapan yang dilakukan murid tersebut sesuai dengan sistem dan strategi kesopanan Model Scollon dan Scollon.

Contoh data percakapan guru ke murid yang menerapkan sistem dan strategi kesopanan model Scollon dan Scollon pada tabel 4.5 ialah :

$P 2$ : 01. AKM ato apa?

$P 2$ : 02. Soalnya ada..halaman 102.

Dari contoh data tersebut, sistem masuk dalam Deference (D+) dan Hierarchy HL (HDw). Dinilai dari Hierarchy HL (H-Dw) komunikasi antara guru ke murid, dari segi usia tinggi ke rendah sehingga menggunakan strategi kesopanan Involvement. Sehingga percakapan yang dilakukan guru tersebut sesuai dengan sistem dan strategi kesopanan Model Scollon dan Scollon.

Tabel 4 : Ringkasan analisis percakapan wali murid dan guru

\begin{tabular}{|c|c|c|c|c|c|c|c|c|c|}
\hline \multirow{2}{*}{ No. } & \multirow{2}{*}{$\begin{array}{c}\text { Perca } \\
\text { kapan }\end{array}$} & \multicolumn{7}{|c|}{ Sistem } & \multicolumn{2}{c|}{ Strategi } & \multicolumn{2}{c|}{ Kesesuaian } \\
\cline { 3 - 9 } & & DEF & SOL & HII & HIU & INV & IND & Sesuai & Tidak \\
\hline & 1 & 11 & & & & 4 & 7 & 7 & 4 \\
\hline 2 & 2 & 16 & & & & 2 & 14 & 14 & 2 \\
\hline 3 & 3 & 8 & & & & & 8 & 8 & \\
\hline 4 & 4 & 13 & & & & 1 & 12 & 12 & 1 \\
\hline 5 & 5 & 21 & & & & 4 & 17 & 17 & 4 \\
\hline & Jumlah & $\mathbf{6 9}$ & & & & $\mathbf{1 1}$ & $\mathbf{5 8}$ & $\mathbf{5 8}$ & $\mathbf{1 1}$ \\
\hline & $\mathbf{\%}$ & $\begin{array}{c}\mathbf{1 0 0} \\
\mathbf{\%}\end{array}$ & & & & $\mathbf{1 5 , 9 \%}$ & $\begin{array}{c}\mathbf{8 4 , 1} \\
\mathbf{\%}\end{array}$ & $\mathbf{8 4 , 1} \%$ & $\mathbf{1 5 , 9} \%$ \\
\hline
\end{tabular}

Dari tabel 4 diperoleh data percakapan wali murid dan guru yang menerapkan sistem dan strategi kesopanan model Scollon dan Scollon sebanyak 58 data atau 84,1\%. 
Tabel 5: Analisis kesopanan percakapan wali murid dan guru

\begin{tabular}{|c|c|c|c|c|c|c|c|c|c|c|}
\hline \multirow[t]{2}{*}{ No. } & \multirow[t]{2}{*}{ Kode } & \multirow[t]{2}{*}{ Data } & \multicolumn{4}{|c|}{ Sistem } & \multicolumn{2}{|c|}{ Strategi } & \multicolumn{2}{|c|}{ Kesesuaian } \\
\hline & & & DEF & SOL & HID & HIU & INV & IND & Sesuai & Tidak \\
\hline 1 & $\mathrm{~T} 1$ & 01. Bu bade curhat. & $\sqrt{ }$ & & & & & $\sqrt{ }$ & $\sqrt{ }$ & \\
\hline 2 & & $\begin{array}{l}\text { 02. Anak-anak belajar } \\
5 \text { menit selebihnya } \\
\text { mainan hp terus. }\end{array}$ & $\sqrt{ }$ & & & & & $\sqrt{ }$ & $\sqrt{ }$ & \\
\hline 3 & & 03. Sedih kulo & $\sqrt{ }$ & & & & & $\sqrt{ }$ & $\sqrt{ }$ & \\
\hline 4 & & 04. Dikasih tau susah & $\sqrt{ }$ & & & & $\sqrt{ }$ & & & $\sqrt{ }$ \\
\hline 5 & $\mathrm{~T} 2$ & 01. Iya mbak & $\sqrt{ }$ & & & & & $\sqrt{ }$ & $\sqrt{ }$ & \\
\hline 6 & $\mathrm{~T} 1$ & $\begin{array}{l}\text { 05. Ditambah. Tempat } \\
\text { Rois pasang wifi. }\end{array}$ & $\sqrt{ }$ & & & & $\sqrt{ }$ & & & $\sqrt{ }$ \\
\hline 7 & $\mathrm{~T} 2$ & $\begin{array}{l}\text { 02. Iya mbak. Besuk } \\
\text { saya google } \\
\text { meetnya }\end{array}$ & $\sqrt{ }$ & & & & & $\sqrt{ }$ & $\sqrt{ }$ & \\
\hline 8 & & $\begin{array}{l}\text { 03. Pakai hp ini atau } \\
\text { hp mas Gantang } \\
\text { sendiri biasanya } \\
\text { mengerjakan } \\
\text { tugas? }\end{array}$ & $\sqrt{ }$ & & & & & $\sqrt{ }$ & $\sqrt{ }$ & \\
\hline 9 & $\mathrm{~T} 1$ & $\begin{array}{l}\text { 06. Kerjasamanya } \\
\text { nggeh bu. }\end{array}$ & $\sqrt{ }$ & & & & & $\sqrt{ }$ & $\sqrt{ }$ & \\
\hline 10 & & $\begin{array}{l}\text { 07. Nanti kalu ke } \\
\text { sekolah dikasih tau }\end{array}$ & $\sqrt{ }$ & & & & $\sqrt{ }$ & & & $\sqrt{ }$ \\
\hline 11 & & $\begin{array}{l}\text { 08. Biasanya kalu } \\
\text { sama guru manut. }\end{array}$ & $\sqrt{ }$ & & & & $\sqrt{ }$ & & & $\sqrt{ }$ \\
\hline & & \begin{tabular}{|l} 
Jumlah \\
\end{tabular} & 11 & & & & 4 & 7 & 7 & 4 \\
\hline
\end{tabular}

\section{Katerangan:}

- Dialog terjadi pada waktu sore, antara pukul 15.33 sampai 15.40

- Pihak yang terlibat dalam percakapan adalah :

$\mathrm{T} 1=\mathrm{Ibu}$, Perempuan, wali murid

$\mathrm{T} 2$ = Ibu, Perempuan, guru

- Topik Pembicaraan : Membicarakan anak

- Nada percakapan : santai

Contoh data percakapan wali murid ke guru yang menerapkan sistem dan strategi kesopanan model Scollon dan Scollon dari tabel 4.9 ialah :

T1 : 01. Bu bade curhat.

T1 : 06. Kerjasamanya nggeh bu.

Dari contoh data tersebut, sistem masuk dalam Deference (D+). Dinilai dari sistem Deference (D+) komunikasi antara wali murid ke guru, terdapat jarak dan tidak saling mengenal sehingga menggunakan strategi kesopanan Independence. Sehingga percakapan yang dilakukan murid tersebut sesuai dengan sistem dan strategi kesopanan Model Scollon dan Scollon.

Contoh data percakapan guru ke wali murid yang menerapkan sistem dan strategi kesopanan model Scollon dan Scollon pada tabel 4.9 ialah :

T2 : 02. Iya mbak. Besuk saya google meetnya

Dari contoh data tersebut, sistem masuk dalam Deference (D+). Dinilai dari sistem Deference $(\mathrm{D}+)$ komunikasi antara guru ke wali murid, karena tidak saling kenal sehingga menggunakan strategi kesopanan Independence. Sehingga percakapan yang dilakukan guru tersebut sesuai dengan sistem dan strategi kesopanan Model Scollon dan Scollon. 
Tabel 6 : Analisis kesopanan percakapan Wali murid dan guru

\begin{tabular}{|c|c|c|c|c|c|c|c|c|c|c|}
\hline \multirow[t]{2}{*}{ No. } & \multirow[t]{2}{*}{ Kode } & \multirow[t]{2}{*}{ Data } & \multicolumn{4}{|c|}{ Sistem } & \multicolumn{2}{|c|}{ Strategi } & \multicolumn{2}{|c|}{ Kesesuaian } \\
\hline & & & DEF & SOL & HID & HIU & INV & IND & Sesuai & Tidak \\
\hline 1 & $\mathrm{~T} 1$ & $\begin{array}{l}\text { 01. Bu, Tyo } \\
\text { mpun garap. }\end{array}$ & $\sqrt{ }$ & & & & & $\sqrt{ }$ & $\sqrt{ }$ & \\
\hline 2 & & $\begin{array}{l}\text { 02.terose tapi } \\
\text { nak liwat } \\
\text { clasroom } \\
\text { boten saget }\end{array}$ & $\sqrt{ }$ & & & & & $\sqrt{ }$ & $\sqrt{ }$ & \\
\hline 3 & & $\begin{array}{l}\text { 03. Niki kulo } \\
\text { tasek kerjo. }\end{array}$ & $\sqrt{ }$ & & & & & $\sqrt{ }$ & $\sqrt{ }$ & \\
\hline 4 & $\mathrm{~T} 2$ & $\begin{array}{l}\text { 01. Nggih. } \\
\text { Besok } \\
\text { dikumpulkan } \\
\text { manual. }\end{array}$ & $\sqrt{ }$ & & & & & $\sqrt{ }$ & $\sqrt{ }$ & \\
\hline 5 & & $\begin{array}{l}\text { 02. Lalu } \\
\text { mengambil } \\
\text { soal yang } \\
\text { untuk hari } \\
\text { Selasa. }\end{array}$ & $\sqrt{ }$ & & & & & $\sqrt{ }$ & $\sqrt{ }$ & \\
\hline 6 & T1 & 04. Nggeh bu & $\sqrt{ }$ & & & & & $\sqrt{ }$ & $\sqrt{ }$ & \\
\hline 7 & & $\begin{array}{l}\text { 05.Susah kulo } \\
\text { bu }\end{array}$ & $\sqrt{ }$ & & & & & $\sqrt{ }$ & $\sqrt{ }$ & \\
\hline 8 & & $\begin{array}{l}\text { 06. Pikiran } \\
\text { malah ra } \\
\text { tenang }\end{array}$ & $\sqrt{ }$ & & & & $\sqrt{ }$ & & & $\sqrt{ }$ \\
\hline 9 & $\mathrm{~T} 2$ & 03.Nggih mbak. & $\sqrt{ }$ & & & & & $\sqrt{ }$ & $\sqrt{ }$ & \\
\hline 10 & & $\begin{array}{l}\text { 04.Yang } \\
\text { penting } \\
\text { dikerjakan di } \\
\text { kertas soal. }\end{array}$ & $\sqrt{ }$ & & & & & $\sqrt{ }$ & $\sqrt{ }$ & \\
\hline 11 & & $\begin{array}{l}\text { 05. Lalu saya } \\
\text { koreksi } \\
\text { manual }\end{array}$ & $\sqrt{ }$ & & & & & $\sqrt{ }$ & $\sqrt{ }$ & \\
\hline 12 & $\mathrm{~T} 1$ & 07.Nggeh buk & $\sqrt{ }$ & & & & & $\sqrt{ }$ & $\sqrt{ }$ & \\
\hline 13 & & $\begin{array}{l}\text { 08.Spuntene } \\
\text { seng katah } \\
\text { nggeh }\end{array}$ & $\sqrt{ }$ & & & & & $\sqrt{ }$ & $\sqrt{ }$ & \\
\hline 14 & & $\begin{array}{l}\text { 09. Tyo bocahe } \\
\text { dablek }\end{array}$ & $\sqrt{ }$ & & & & $\sqrt{ }$ & & & $\sqrt{ }$ \\
\hline 15 & & $\begin{array}{l}\text { 10. mboten } \\
\text { nitekne nak } \\
\text { dikandani }\end{array}$ & $\sqrt{ }$ & & & & & $\sqrt{ }$ & $\sqrt{ }$ & \\
\hline 16 & & $\begin{array}{l}\text { 11.Kulo sampek } \\
\text { mutung }\end{array}$ & $\sqrt{ }$ & & & & & $\sqrt{ }$ & $\sqrt{ }$ & \\
\hline & & Jumlah & 16 & & & & 2 & 14 & 14 & 2 \\
\hline
\end{tabular}

\section{Katerangan:}

- Dialog terjadi pada waktu siang, antara pukul 12.43 sampai 12.56 di kantor.

- Pihak yang terlibat dalam percakapan adalah :

$\mathrm{T} 1$ = Ibu, Perempuan, wali murid

$\mathrm{T} 2$ = Ibu, Perempuan, guru

- Topik Pembicaraan : Membicarakan anak (murid)

- Nada percakapan : santai dan serius 
Contoh data percakapan wali murid ke guru yang menerapkan sistem dan strategi kesopanan model Scollon dan Scollon dari tabel 4.10 ialah :

T1 : 01. Bu, Tyo mpun garap.

$T 1: 02$. terose tapi nak liwat clasroom boten saget

Dari contoh data tersebut, sistem masuk dalam Deference (D+). Dinilai dari sistem Deference (D+) komunikasi antara wali murid ke guru, terdapat jarak dan tidak saling mengenal sehingga menggunakan strategi kesopanan Independence. Sehingga percakapan yang dilakukan murid tersebut sesuai dengan sistem dan strategi kesopanan Model Scollon dan Scollon.

Contoh data percakapan guru ke wali murid yang menerapkan sistem dan strategi kesopanan model Scollon dan Scollon pada tabel 4.10 ialah :

T2 : 01. Nggih. Besok dikumpulkan manual.

T2 : 02. Lalu mengambil soal yang untuk hari Selasa.

Dari contoh data tersebut, sistem masuk dalam Deference (D+). Dinilai dari sistem Deference (D+) komunikasi antara guru ke wali murid, karena tidak saling kenal sehingga menggunakan strategi kesopanan Independence. Sehingga percakapan yang dilakukan guru tersebut sesuai dengan sistem dan strategi kesopanan Model Scollon dan Scollon.

Tabel 7 : Ringkasan analisis percakapan murid dan murid

\begin{tabular}{|c|c|c|c|c|c|c|c|c|c|}
\hline \multirow[t]{3}{*}{ No. } & \multirow{3}{*}{$\begin{array}{l}\text { Perca } \\
\text { kapan }\end{array}$} & \multicolumn{8}{|c|}{ Jumlah dalam \% } \\
\hline & & \multicolumn{4}{|c|}{ Sistem } & \multicolumn{2}{|c|}{ Strategi } & \multicolumn{2}{|c|}{ Kesesuaian } \\
\hline & & DEF & SOL & HID & $\begin{array}{c}\text { HI } \\
\text { U }\end{array}$ & INV & $\begin{array}{l}\text { IN } \\
\text { D }\end{array}$ & Sesuai & Tidak \\
\hline 1 & 1 & & 16 & & & 16 & & 16 & \\
\hline 2 & 2 & & 14 & & & 14 & & 14 & \\
\hline 3 & 3 & & 7 & & & 7 & & 7 & \\
\hline \multirow[t]{3}{*}{4} & 4 & & 5 & & & 5 & & 5 & \\
\hline & Jumlah & & 42 & & & 42 & & 42 & \\
\hline & $\%$ & - & $100 \%$ & - & - & $\begin{array}{c}100 \\
\%\end{array}$ & - & $100 \%$ & - \\
\hline
\end{tabular}

Dari tabel 7 diperoleh data percakapan murid dan murid yang menerapkan sistem dan strategi kesopanan model Scollon dan Scollon sebanyak 42 data atau $100 \%$.

Tabel 8 : Analisis kesopanan percakapan murid dan murid

\begin{tabular}{|l|l|l|c|c|c|c|c|c|c|c|}
\hline No. & Kode & \multicolumn{1}{|c|}{ Data } & \multicolumn{3}{c|}{ Sistem } & \multicolumn{2}{c|}{ Strategi } & \multicolumn{2}{c|}{ Kesesuaian } \\
\hline & & DEF & SOL & HID & HIU & INV & IND & \multicolumn{2}{c|}{ Sesuai } & Tidak \\
\hline 1 & Y1 & $\begin{array}{l}\text { 01. Tugas b.Jawa halaman } \\
\text { berapa }\end{array}$ & & $\sqrt{ }$ & & & $\sqrt{ }$ & & $\sqrt{ }$ & \\
\hline 2 & Y2 & $\begin{array}{c}\text { 01. Tugas b.Jawa halaman } \\
\text { 52 sampai 54 }\end{array}$ & & $\sqrt{ }$ & & & $\sqrt{ }$ & & $\sqrt{ }$ & \\
\hline 3 & Y1 & $\begin{array}{c}\text { 02. Yang dikerjakan sampai } \\
\text { no brp }\end{array}$ & & $\sqrt{ }$ & & & $\sqrt{ }$ & & $\sqrt{ }$ & \\
\hline 4 & Y2 & $\begin{array}{l}\text { 02. No 1 sampai 10 sama } \\
\text { titik-titik }\end{array}$ & & $\sqrt{ }$ & & & $\sqrt{ }$ & & $\sqrt{ }$ & \\
\hline 5 & Y1 & 03. Makasih & & $\sqrt{ }$ & & & $\sqrt{ }$ & & $\sqrt{ }$ & \\
\hline 6 & Y2 & 03. Sama-sama & & $\sqrt{ }$ & & & $\sqrt{ }$ & & $\sqrt{ }$ & \\
\hline 7 & Y1 & 04. Aku mau tanya lagi nih & & $\sqrt{ }$ & & & $\sqrt{ }$ & & $\sqrt{ }$ & \\
\hline 8 & Y2 & 04. Iya knp & & $\sqrt{ }$ & & & $\sqrt{ }$ & & $\sqrt{ }$ & \\
\hline 9 & Y1 & $\begin{array}{c}\text { 05. Kalu menurutku b.Jawa } \\
\text { itu gampang }\end{array}$ & & $\sqrt{ }$ & & & $\sqrt{ }$ & & $\sqrt{ }$ & \\
\hline 10 & & 06. Kalu menurutmu gimana & & $\sqrt{ }$ & & & $\sqrt{ }$ & & $\sqrt{ }$ & \\
\hline 11 & Y2 & $\begin{array}{c}\text { 05. Menurut ku juga } \\
\text { gampang }\end{array}$ & & $\sqrt{ }$ & & & $\sqrt{ }$ & & $\sqrt{ }$ & \\
\hline
\end{tabular}




\begin{tabular}{|c|c|l|c|c|c|c|c|c|c|c|}
\hline 12 & & $\begin{array}{c}\text { 06. Kamu udah dikerjakan } \\
\text { belum b.Jawa nya }\end{array}$ & & $\sqrt{ }$ & & & $\sqrt{ }$ & & $\sqrt{ }$ & \\
\hline 13 & Y1 & 07. Ini udah selesai & & $\sqrt{ }$ & & & $\sqrt{ }$ & & $\sqrt{ }$ & \\
\hline 14 & Y2 & 07. Sama & & $\sqrt{ }$ & & & $\sqrt{ }$ & & $\sqrt{ }$ & \\
\hline & & Jumlah & & $\mathbf{1 4}$ & & & $\mathbf{1 4}$ & & $\mathbf{1 4}$ & \\
\hline
\end{tabular}

\section{Katerangan:}

- Dialog terjadi pada waktu siang, antara pukul 13.52 sampai 14.05

- Pihak yang terlibat dalam percakapan adalah :

$\mathrm{Y} 1$ = Anak, perempuan, murid

Y2 = Anak, perempuan, murid

- Topik Pembicaraan : Membahas tugas Bahasa Jawa

- Nada percakapan : santai dan serius

Contoh data percakapan wali murid ke guru yang menerapkan sistem dan strategi kesopanan model Scollon dan Scollon dari tabel 4.16 ialah :

$Y 1$ : 07. Ini udah selesai

$Y 2$ : 07. Sama

Dari contoh data tersebut, sistem masuk dalam Solidarity (D-). Dinilai dari sistem Solidarity (D-) komunikasi antara murid dan murid, tidak ada jarak dan saling mengenal sehingga menggunakan strategi kesopanan Involvement. Sehingga percakapan yang dilakukan murid tersebut sesuai dengan sistem dan strategi kesopanan Model Scollon dan Scollon.

Tabel 9: Analisis kesopanan percakapan murid dan murid

\begin{tabular}{|l|l|l|l|c|c|c|c|c|c|c|}
\hline No. & Kode & Data & \multicolumn{3}{c|}{ Sistem } & \multicolumn{2}{c|}{ Strategi } & \multicolumn{2}{c|}{ Kesesuaian } \\
\hline 1 & Y1 & $\begin{array}{c}\text { 01 Tugas } \\
\text { matematika } \\
\text { hal brp? }\end{array}$ & & $\sqrt{ }$ & & & $\sqrt{ }$ & & $\sqrt{ }$ & \\
\hline 2 & Y2 & 01. 103 & & & & & & & & \\
\hline 3 & Y1 & $\begin{array}{c}\text { 02. Yang } \\
\text { dikerjakan } \\
\text { sampai no } \\
\text { brp }\end{array}$ & & $\sqrt{ }$ & & & $\sqrt{ }$ & & $\sqrt{ }$ & \\
\hline 4 & Y2 & 02. 1 sampai 5 & & $\sqrt{ }$ & & & $\sqrt{ }$ & & $\sqrt{ }$ & \\
\hline 5 & Y1 & $\begin{array}{c}\text { 03. Untuk no 2 } \\
\text { menurutku } \\
\text { dibagi }\end{array}$ & & $\sqrt{ }$ & & & $\sqrt{ }$ & & $\sqrt{ }$ & \\
\hline 6 & & $\begin{array}{c}\text { 04. klo kamu } \\
\text { gimana }\end{array}$ & & $\sqrt{ }$ & & & $\sqrt{ }$ & & $\sqrt{ }$ & \\
\hline 7 & Y2 & $\begin{array}{c}\text { 03. Sam } \\
\text { menurut ku } \\
\text { juga }\end{array}$ & & $\sqrt{ }$ & & & $\sqrt{ }$ & & $\sqrt{ }$ & \\
\hline & & Jumlah & & $\mathbf{7}$ & & & $\mathbf{7}$ & & $\mathbf{7}$ & \\
\hline
\end{tabular}

\section{Katerangan:}

- Dialog terjadi pada waktu siang , antara pukul 13.50 sampai 13.56

- Pihak yang terlibat dalam percakapan adalah :

$\mathrm{Y} 1$ = Anak, perempuan, murid

Y2 = Anak, perempuan, murid

- Topik Pembicaraan : Membahas tugas matematika

- Nada percakapan : santai

Contoh data percakapan wali murid ke guru yang menerapkan sistem dan strategi kesopanan model Scollon dan Scollon dari tabel 4.15 ialah :

Y1 : 01 Tugas matematika hal brp? 
$Y 2: 01.103$

Dari contoh data tersebut, sistem masuk dalam Solidarity (D-). Dinilai dari sistem Solidarity (D-) komunikasi antara murid dan murid, tidak ada jarak dan saling mengenal sehingga menggunakan strategi kesopanan Involvement. Sehingga percakapan yang dilakukan murid tersebut sesuai dengan sistem dan strategi kesopanan Model Scollon dan Scollon.

\section{PEMBAHASAN}

Penjelasan dalam bab ini berhubungan dengan penerapan strategi kesopanan berbahasa di WhatsApp Group Kelas 5 SDN Sumberbening 1, Kabupaten Ngawi pada Masa Pandemi Covid-19 dengan sistem dan strategi kesopanan model Scollon dan Scollon (2001 : 54-57), pada kegiatan percakapan di WhatsApp group kelas 5 yang dibagi menjadi tiga kelompok, yakni percakapan murid dengan guru, percakapan wali murid dan guru, percakapan murid dan murid.

Pokok-pokok temuan penelitian tentang penerapan strategi kesopanan berbahasa di WhatsApp Group Kelas 5 SDN Sumberbening 1 dapat dirumuskan bahwa penggunaan bahasa penutur dan lawan tutur tersebut masih memperhatikan strategi kesopanan berbahasa karena sistem dan strategi kesopanan masih diperhatikan baik.

Jumlah penerapan strategi kesopanan dalam percakapan antara murid dan guru berjumlah 37 data temuan atau sebanyak $66,1 \%$. Percakapan antara wali murid dan guru berjumlah 58 data temuan atau sebanyak $84,1 \%$. Percakapan antara murid dan murid berjumlah 42 data temuan atau sebanyak $100 \%$. Dalam percakapan murid dan guru sebanyak $66,1 \%$, disini setidaknya murid masih memperhatikan sistem dan strategi kesopanan berbahasa. Murid masih menggunakan strategi kesopanan berbahasa dengan cukup baik. Dibandingkan percakapan murid dan guru, percakapan wali murid dan guru lebih banyak lagi yakni sebanyak 84,1\%. Percakapan wali murid dan guru dengan Sistem Kehormatan Kesopanan (Diference (D+)), masih sangat memperhatikan strategi kesopanan berbahasa dengan baik. Kemudian percakapan murid dan murid sebanyak $100 \%$ karena komunikasi antara murid dan murid masuk dalam Sistem Kesopanan Solidaritas (D-), mereka saling mengenal, sehingga menggunakan strategi kesopanan keterlibatan.

Dari pembahasan diatas antara penerapan dan pelanggaran menurut teori Sistem dan Strategi Kesopanan Model Scollon dan Scollon (2001:54-57) lebih banyak penerapan. Disini bisa dipahami bahwa percakapan yang terjadi antara murid dan guru, walimurid dan guru, murid dan murid masih memperhatikan strategi kesopanan berbahasa yang baik. Bisa dilihat juga dari percakapan masih menggunakan campuran Bahasa Indonesia dan Bahasa Jawa, dimana Bahasa Jawa masih digunakan sebagai pelajaran muatan lokal. Salah satu materi bahasa Jawa yang sudah diajarkan sejak tingkat sekolah dasar yaitu unggah-ungguh bahasa Jawa. Materi unggah-ungguh atau tingkat tutur bahasa Jawa memiliki manfaat yang penting karena mengajarkan peserta didik untuk menghormati orang yang lebih tua atau cara berbicara yang baik terhadap orang lain. Materi unggah-ungguh menjadi salah satu materi yang dianggap sulit untuk dipelajari dikarenakan terdapat tingkatan- tingkatan bahasa yang digunakan untuk berbicara dengan orang lain. Peserta didik sekolah dasar adalah mereka yang sedang menjalani tahap perkembangan masa kanak-kanak dan memasuki masa remaja awal. Pada masa usia sekolah dasar, anak diharapkan memperoleh pengetahuan dasar yang dipandang sangat penting bagi persiapan dan penyesuaian diri terhadap kehidupan di masa dewasa (Iskandarwassid, 2009:139).

Bahasa Jawa memiliki beberapa tingkat tutur (speech levels) atau undha-usuk atau unggahungguhing basa. Penggunaan bahasa Jawa sangat terikat dengan tingkat tutur tersebut. Tingkat tutur dalam bahasa Jawa memiliki jumlah yang tidak sedikit. Terdapat 4 tingkat tutur dalam bahasa Jawa, yaitu ngoko lugu, ngoko alus, krama lugu, dan krama inggil. Penggunaan tingkat tutur tersebut disesuaikan dengan lawan bicara (Sasangka, 2005: 19). Menurut Esti dan Hardyanto (2010: 47) tingkat tutur bahasa Jawa (unggah-ungguhing basa) pada dasarnya ada dua macam, yaitu ragam ngoko dan ragam krama. Ragam ngoko meliputi ngoko lugu dan ngoko alus. Ragam krama meliputi krama lugu dan kramaalus. Menurut Sasangka (2005: xxi) krama lugu adalah suatu ragam yang kosakatanya terdiri dari leksikon krama, madya, netral, atau ngoko dan dapat ditambah dengan leksikon krama inggil.

Pembelajaran Bahasa Jawa bagi peserta didik dirasa sangatlah susah. Sebagian masyarakat Jawa di era modern menganggap bahwa bahasa Jawa adalah bahasa yang rumit sehingga banyak diantara mereka merasa takut ketika menggunakan bahasa Jawa. Bahasa Jawa dianggap rumit karena di dalam 
pemakaiannya, penutur harus mempertimbangkan unggah-ungguh yang secara normatif terdiri dari tingkatan-tingkatan atau undha-usuk yang cukup beragam. Sedangkan Magnis Suseno (1985:11) menuliskan bahwa yang disebut orang Jawa adalah orang yang bahasa ibunya bahasa Jawa yang sebenarnya. Bahasa Jawa dalam arti yang sebenarnya dijumpai di Jawa Tengah dan Jawa Timur. Jadi, sebenarnya cukup ironis jika sebagai anggota masyarakat Jawa atau dengan istilah lain sebagai orang Jawa tidak mampu berbahasa Jawa.

Sejalan dengan pemikiran di atas, bahwa ibu sebagai anggota masyarakat Jawa dan sekaligus pemegang peranan penting dalam pembentukan keluarga, mempunyai tangung jawab yang cukup besar dalam pembelajaran unggah-ungguh kepada putra-putrinya. Namun, kenyataan tentang keberbatasan para ibu dalam penguasaan bahasa Jawa khususnya dalam hal unggah-ungguh sudah bukan hal yang aneh. Pernyataan wong Jowo ora nJawani semakin tampak nyata. Kenyataan ini tidak lain merupakan dampak dari pesatnya arus globalisasi. Masyarakat Jawa merasa kesulitan berbahasa Jawa, terutama di lingkungan perkotaan. Kesulitan tersebut dapat disebabkan oleh terbatasnya pembelajaran bahasa Jawa di keluarga atau terbatasnya komunitas penutur bahasa Jawa. Selain itu, pembinaan baik dari segi teoretis maupun praktis tentang penerapan unggah-ungguh bahasa Jawa khusunya di lingkungan masyarakat memang jarang dijumpai.

Pada dasarnya kesalahan penerapan unggah-ungguh bahasa Jawa tidak hanya muncul di lingkungan perkotaan tetapi di pedesaan yang semula menjadi basis pemakai bahasa Jawa juga sudah sering dijumpai. Apalagi di lingkungan perkotaan, terutama di perumahan yang pada umumnya dipenuhi oleh penduduk dari segala penjuru. Maka bahasa Indonesialah yang membudaya. Kalau pun di lingkungan tersebut bertemu dengan sesama orang Jawa dan berkomunikasi dengan bahasa Jawa, yang sering terjadi adalah pemakaian bahasa Jawa yang kasar dan sering terdapat kesalahan dalam penerapan unggah-ungguh. Yang seharusnya tataran krama itu untuk orang lain, tapi justru dipakai untuk dirinya sendiri. Contoh: Nuwun sewu kula badhe kondur rumiyin. Pemakaian kata kondur untuk dirinya sendiri tidak tepat, seharusnya wangsul. Penerapan unggah-ungguh yang tidak tepat akan memunculkan kesan tidak etis.

Penyimpangan-penyimpangan lain yang sejenis sering terjadi tapi anehnya tidak pernah dilakukan pembenaran. Ketika seseorang yang kebetulan paham tentang tingkat tutur bahasa Jawa menjumpai penyimpangan semacam itu pun merasa enggan untuk membetulkan karena khawatir dapat menyinggung perasaan penutur salah tersebut. Oleh karena itu, yang terjadi adalah kesalahan-kesalahan semakin menumpuk dan mengendap dan akhirnya menjadi hal yang biasa. Akibatnya proses pembelajaran unggah-ungguh terhadap anak dan keluarganya pun dilakukan dengan bekal pengetahuan yang masih sangat minim bahkan kadang kala malah salah.

Sejalan dengan konsep di atas bahwa peranan ibu dalam keluarga sangat penting dalam membentuk corak kepribadian anak. Melalui pendidikan agama, budi pekerti, dan tata krama, tentunya akan mampu mewujudkan pola perilaku keseharian sebagai anak yang santun. Sikap kesantunan tersebut akan tercermin dari bagaimana cara anak bertindak dan bertutur kata. Oleh karena itu, pembelajaran bahasa dalam lingkungan keluarga sangatlah berarti. Melalui bahasanya seorang anak akan dikenal kepribadiannya. Bahkan sering dikatakan bahwa bahasa menunjukkan bangsa, artinya melalui tutur katanya akan mencerminkan kepribadiannya. Dalam hal ini peranan ibu dalam pembelajaran bahasa sangat menentukan pola kepribadian anak dan keluarganya.

Sebagai masyarakat Jawa yang sekaligus tinggal tanah Jawa, mestinya penguasaan terhadap bahasa Jawa yang nota bene sebagai bahasa ibu, sudah tidak diragukan lagi. Sudah sewajarnya jika ibuibu di Jawa mengajarkan bahasa Jawa kepada putra-putrinya sebagai bahasa dalam komunikasi sehariharinya.

Dengan demikian, berarti bahwa paling tidak bagi masyarakat Jawa unggah- ungguh itu masih tetap perlu dilestarikan sampai ditemukan bentuk-bentuknya yang baru dalam tata masyarakat nasional Indonesia. Untuk menanamkannya tentu saja peranan keluarga sangat besar, terutama dalam menciptakan kondisi sedemikian rupa hingga anak-anak sejak kecil telah dibawa ke dalam pola perilaku unggah- ungguh lengkap dengan jiwanya.

Penerapan unggah-ungguh bahasa Jawa sebagai bentuk perwujudan sopan- santun di masyarakat Jawa yang terdiri dari pocapan dan patrap tersebut adalah suatu tataran atau aturan yang secara turuntemurun dan berkembang dalam suatu budaya masyarakat, yang bermanfaat dalam pergaulan dengan orang lain agar terjalin hubungan yang akrab, saling pengertian, hormat-menghormati menurut adat yang telah ditentukan (Suharti, 2006). Oleh karena itu, dapat ditegaskan lagi bahwa penerapan tata 
krama atau unggah-ungguh wajib diajarkan oleh orang tua kepada anaknya. Ada yang berpendapat bahwa baik buruknya tingkah laku anak merupakan cerminan tingkah laku orang tuanya sendiri. Dalam hal ini orang tua sebagai unsur keluarga dan masyarakat memiliki peranan yang sangat penting. Jika sebagai orang tua mampu menjalankan peranannya untuk menjadi cerminan perilaku sopan santun kepada anak-anaknya berarti upaya pembangunan karakter (Character Building) akan dapat terwujud.

Kaitannya dengan pembangunan karakter, melalui pembelajaran bahasa Jawa khususnya penerapan ungah-ungguh yang sesuai dengan situasi dan konteksnya merupakan pendidikan ke arah pembinaan budi luhur. Pembinaan budi luhur atau watak utama melalui penerapan unggah-ungguh berbahasa Jawa adalah realisasi sopan santun. Lebih lanjut dijelaskan oleh Suharti (2006) bahwa konsep sopan santun tentang keseimbangan merupakan sarana untuk membiasakan pengguna bahasa Jawa agar selalu menerapkan tepa slira, saling menghormati yang berdasarkan pada deduga, prayoga, watara dan reringa.

Sejalan dengan pemikiran di atas bahwa ibu sebagai anggota masyarakat Jawa dan sekaligus pemegang peranan penting pembentukan keluarga, mempunyai tangung jawab yang cukup besar dalam pembelajaran unggah-ungguh kepada putra putrinya. Dengan pembelajaran unggah-ungguh akan mampu membentuk kepribadian anak yang akan tercermin dalam pola perilaku kesehariannya. Selain itu melalui pembelajaran unggah-ungguh secara tidak langsung ikut andil dalam rangka pemertahanan budaya dan pembentukan generasi yang berkarakater. Oleh karena itu, dengan mengacu pada pemikiran R.A. Kartini bahwa sebagai seorang ibu yang akan mendidik anak-anaknya dalam keluarga maka ibu harus mempunyai pengetahuan yang cukup. Dengan demikian, sungguh memprihatinkan jika dalam pembelajaran unggah-ungguh bahasa Jawa para ibu rumah tangga tidak menguasai tentang penerapan unggah-ungguh bahasa Jawa sehingga mana mungkin akan dapat membelajarkan kepada putraputrinya.

Bahasa Jawa mengandung nilai budi pekerti yang luhur (Harjawiyana dan Supriya, 2009, p.9). Nilai luhur bahasa Jawa tampak pada rasa kesantunan dan kepekaan rasa yang berdasar pada prinsip menghormati orang lain. Ibid melalui Eelen (2001, p.5) menyebutkan kesantunan sangat penting bagi struktur kehidupan sosial dan masyarakat, sebagai ekspresi hubungan sosial)." Kesantunan berbahasa merupakan salah satu cara untuk mewujudkan kerukunan dalam hidup bermasayarakat.

Kesantunan berbahasa adalah sebuah sistem hubungan interpersonal yang didesain untuk memfasilitasi interaksi dengan meminimalisasi pertentangan dan konfrontasi yang melekat pada manusia (Lakoff melalui Eelen, 2001, p.2). Penghindaran konflik ini dilakukan dengan cara berbahasa yang menyenangkan lawan tuturnya. Mewujudkan bahasa yang santun tidak dapat dilepaskan dari konteks tutur dan faktor sosial budaya yang melatarinya.

Para ahli telah mengkaji tentang kesantunan berbahasa secara universal dan merumuskan berbagai macam strategi untuk menciptakan kesantunan dalam berkomunikasi. Ahli yang terkenal dengan kajiannya tentang kesantunan berbahasa antara lain Leech (1993), Brown- Levinson (1987), dan Robin T. Lakoff. Namun, sebenarnya kriteria penilaian kesantunan suatu bahasa tidak pernah lepas dari budaya yang mengikatnya. Ada aspek-aspek tertentu dalam suatu kebudayaan yang tidak dimiliki oleh kebudayaan lain (Sukarno, 2010, p.59). Meskipun tidak menutup kemungkinan adanya prinsip dan kriteria kesantunan yang sama dengan kebudayaan lain.

Demikian juga dengan bahasa Jawa yang tidak terlepas dari budaya Jawa. Hal ini menyebabkan bahasa Jawa memiliki kriteria-kriteria penentu kesantunannya sendiri. Asim Gunarwan (2005) telah merumuskan prinsip kesantunan berbahasa Jawa. Berdasarkan prinsip kesantunan berbahasa tersebut dan dipadukan dengan prinsip kesantunan secara universal, diperoleh kriteria kesantunan berbahasa Jawa. Kriteria kesantunan berbahasa Jawa meliputi kesantunan pada aspek isi tuturan dan kesantunan pada penggunaan unggah-ungguh basa yang didu- kung oleh faktor non-kebahasaan (gerak-gerik tubuh, tinggi rendah nada bicara, ekspresi muka). Namun, dalam penelitian ini difokuskan pada aspek kebahasaan saja.

Untuk aspek kebahasaan lebih menekankan pada bentuk, nilai, dan fungsi kesantunan berbahasa. Bentuk kesantunan berbahasa dapat dilihat dari bentuk lokusi tindak tuturnya, bermodus deklaratif atau kalimat berita, bermodus interogatif atau kalimat pertanyaan, atau bermodus imperatif atau kalimat perintah. Nilai kesantunan berbahasa dapat dilihat dari ilokusi dan isi tuturan yang mematuhi prinsipprinsip kesantunan berbahasa Jawa dan ketepatan peng- gunaan unggah-ungguh basa. Fungsi kesantunan berbahasa dapat dilihat dari perlokusi atau efek yang ditimbulkan dari penggunaan tindak tutur tersebut. 
Namun, semua penentuan nilai kesantunan berbahasa juga sangat dipengaruhi oleh konteks tutur yang melingkupinya. Dell Hymes melalui Wardhaugh (1986, pp.245-246) menye- butkan akronim SPEAKING untuk menjelaskan komponen-komponen yang termasuk dalam konteks tutur, yang meliputi S (Setting and Scene), P (Participant), E (Ends), A (Act Sequences), K (Key), I (Instrumentalities), N (Norm), G (Genre). Agar menghasilkan tuturan yang santun, penutur harus memperhatikan konteks tutur tersebut ketika berkomunikasi.

Interaksi dalam proses pembelajaran juga termasuk peristiwa komunikasi yang membutuhkan kesantunan berbahasa. Masalah tentang bentuk, nilai, dan fungsi kesantunan berbahasa Jawa sebaiknya dipahami dengan baik oleh guru dan siswa untuk menciptakan kenyamanan dalam proses pembelajaran. Kesantunan berbahasa akan memperlancar proses transfer pengetahuan karena guru dan siswa berada dalam situasi yang kondusif dan menyenangkan. Bahasa santun yang digunakan guru dalam berinteraksi dengan siswa juga akan memberikan input atau contoh konkret penggunaan bahasa yang baik dan santun dalam berkomunikasi kepada siswa.

Melihat peran bahasa di dalam kelas sebagai media transfer pengetahuan, maka bahasa dalam ranah pembelajaran lebih menekankan fungsi komunikasi daripada fungsi keindahan bahasa. Pemahaman pengetahuan atau pesan yang disampaikan melalui bahasa yang diguna- kan oleh guru dan siswa lebih ditekankan. Selain itu, tuturan di dalam kelas bersifat formal dan transaksional. Namun, penggunaan bahasa dalam interaksi pembelajaran tetap harus memperhatikan kesantunan berbahasa agar komunikasi tetap beretika, yaitu dengan menggunakan unggah-ungguh basa Jawa yang umum digunakan dalam proses pembelajaran, seperti ragam ngoko, ngoko alus, krama, dan krama inggil.

Dari penjelasan tersebut dapat dilihat pentingnya kesantunan berbahasa dalam berkomunikasi dan berinteraksi, termasuk komunikasi yang terjadi antara guru dan siswa di dalam kelas. Namun, di era globalisasi seperti sekarang ini pemahaman dan penguasaan kesantunan berbahasa semakin menurun. Hal ini dapat dilihat pada contoh nyata di lapangan.

Nilai kesantunan berbahasa ditentukan dari penilaian aspek isi tuturan dan penilaian aspek unggah-ungguh basa yang didukung aspek paralingual (ekspresi muka, tinggi rendah nada bicara, gerak-gerik tubuh) yang sesuai dengan konteks tuturnya. Jadi, untuk menentukan nilai kesantunan berbahasa, nilai kesantunan ketiga aspek tersebut tidak dapat dipisahkan.

Isi tuturan dinilai santun apabila mematuhi prinsip kesantunan berbahasa Jawa. Prinsip kesantunan berbahasa Jawa meliputi prinsip kebijaksanaan, prinsip formalitas-tepa selira, prinsip penghargaan dan kerendahan hati- andhap asor, dan prinsip ketidaklangsungan.

Prinsip kebijaksanaan berkaitan dengan sejauh mana tindakan yang dilakukan penutur memberikan keuntungan/kerugian pada mitra tutur. Prinsip formalitas-tepa selira berkaitan dengan cara penyampaian tuturan, apakah penu- tur memaksa mitra tutur untuk mengikuti apa yang dituturkan atau tidak. Prinsip penghargaan dan kerendahan hati-andhap asor berkaitan de- ngan respon yang diberikan oleh penutur terhadap tindakan/tuturan mitra tutur, menghargai atau tidak. Kemudian terakhir, prinsip ketidaklangsungan berkaitan dengan daya ilokusi yang terkandung dalam tuturan, diungkapkan secara langsung/terselubung. Nilai kesantunan dilihat dari pencapaian indikator masing-masing prinsip kesantunan yang berkisar dari tidak santun sampai dengan sangat santun. Semakin isi tuturan mematuhi prinsip-prinsip kesantunan berbahasa Jawa tersebut maka nilai kesantunannya semakin tinggi.

Unggah-ungguh basa juga menentukan kesantunan berbahasa dari tuturan yang diucapkan. Penggunaan unggah-ungguh basa yang tepat akan membuat suatu tuturan menjadi santun, begitupun sebaliknya. Hasil penelitian menunjukkan bahwa unggah-ungguh basa yang paling banyak digunakan guru untuk berinteraksi dengan siswa adalah ragam bahasa ngoko alus, kemudian ragam bahasa krama, krama inggil, dan paling sedikit digunakan adalah ragam bahasa ngoko.

Penilaian kesantunan pada aspek unggah- ungguh basa, ketika guru berinteraksi dengan siswa menggunakan ragam bahasa krama dan krama inggil maka bernilai sangat santun, apapun motif yang berada di balik penggunaan ragam bahasa tersebut. Hal ini disebabkan guru sangat menghargai siswa. Ketika guru berinteraksi dan berkomunikasi menggunakan ragam bahasa ngoko alus dan ngoko (tidak kasar) maka tuturan guru tersebut bernilai santun karena masih menunjukkan adanya penghargaan guru terhadap siswa.

Penanaman kesopanan selain melalui materi unggah-ungguh atau tingkat tutur bahasa Jawa juga dapat dilakukan melalui penanaman Budi Pekerti. Ki Hajar Dewantoro, pendiri Taman Siswa menekankan betapa pentingnya pendidikan budi pekerti sejak usia dini di sekolah. Mata pelajaran ini memfasilitasi siswa guna mengkaji nilai-nilai humanitas, misalnya prinsip kejujuran, memperjuangkan 
Budi pekerti bukan merupakan mata pelajaran, tetapi merupakan program pendidikan untuk menciptakan suasana kondusif dalam menerapkan nilai-nilai budi pekerti. Pendidikan budi pekerti dilaksanakan setiap saat selama kurun waktu berlangsungnya kegiatan pembelajaran dalam kelas di lingkungan sekolah dengan melibatkan seluruh masyarakat sekolah. Jadi pendidikan budi pekerti yang dimaksud adalah upaya untuk membekali peserta didik melalui bimbingan dan pengajaran yang berisi nilai - nilai perilaku manusia yang dapat diukur melalui norma agama, norma hukum, tata krama dan sopan santun, serta norma budaya atau adat istiadat masyarakat. Budi pekerti diwujudkan dalam bentuk perbuatan, perkataan, pikiran, sikap, perasaan dan kepribadian anak didik.

Tujuan pendidikan budi pekerti yaitu agar peserta didik memiliki kemampuan dan kecakapan berpikir, menjadi anggota masyarakat yang bermanfaat dan memiliki kemampuan yang terpuji. Dalam rangka mewujudkan pendidikan nasional, pendidikan budi pekerti yang diintegrasikan sejumlah mata pelajaran yang relevan mempunyai tujuan agar peserta didik mampu menggunakan pengetahuan, mengkaji dan menginternalisasi nilai dan keterampilan sosial untuk mengembangkan akhlak mulia yang diwujudkan dalam perilaku sehari-hari. Secara rinci tujuan pendidikan budi pekerti menurut Cahyoto (2002: 9-13) dapat dijelaskan sebagai berikut : (1) mendorong kebiasaan berperilaku terpuji sesuai nilai- nilai universal dan tradisi budaya yang religius; (2) menanamkan jiwa kepemimpinan dan tanggung jawab; (3) memupuk ketegaran mental peserta didik agar tidak terjerumus pada perilaku yang menyimpang, baik secara individu maupun sosial, dan (4) meningkatkan kemampuan untuk menghindari sifat tercela yang dapat merusak diri sendiri, orang lain, dan lingkungan.

Pendidikan budi pekerti merupakan program pengajaran di sekolah yang bertujuan mengembangkan nilai-nilai yang berakhlak mulia melalui kejujuran, disiplin dan kerja sama yang menekankan ranah afektif (perasaan dan sikap) tanpa meninggalkan ranah kognitif (berpikir rasional) dan ranah skill (keterampilan). Pendidikan budi pekerti tidak hanya hafal kata-kata bijak atau mampu menjawab soal ujian, tetapi lebih berorientasi kepada perilaku dalam berinteraksi. Sebenarnya pendidikan budi pekerti di sekolah lebih mudah ditanamkan di tingkat dasar, namun anak masih membutuhkan pendidikan yang berkelanjut- an di tingkat menengah dan atas.

Hal utama pendidikan budi pekerti di sekolah adalah keberadaan guru sebagai tauladan peserta didik, guru bukan sekadar mengajarkan mata pelajaran, seyogyanya guru harus kreatif dalam mendidik siswa. Di sela-sela penyampaian pelajaran guru juga menyampaikan nilai-nilai dan norma positif, sehingga peserta didik tidak hanya dibekali keilmuan saja tapi juga budi pekerti. Jika orang tua di rumah sebagai figur budi pekerti luhur, guru di sekolah menjadi tauladan.

Berkaitan tugas dan peran guru dalam pendidikan budi pekerti, guru dituntut mampu memberikan nuansa yang tidak hanya sekadar menyampaikan ilmu pengetahuan saja, tetapi dapat mengubah perilaku peserta didik untuk menjadi manusia berbudi luhur.

Pendidikan budi pekerti dilakukan sebagai upaya pembinaan bagi peserta didik agar menjadi orang-orang yang berwatak luhur dan berkepribadian yang terpuji sesuai dengan nilai positif, norma agama, dan kemasyarakatan serta budaya bangsa. Pencerminan watak tersebutberupa religius, jujur, toleran, disiplin, bertanggung jawab, percaya diri, peka terhadap lingkungan, demokratis, cerdas, kreatif, dan inovatif.

Sekolah bukan semata-mata hanya meningkatkan kemampuan intelektual, tapi juga memupuk kejujuran, kebenaran dan nilai pengabdian dalam kehidupan ber- masyarakat, meskipun sekolah telah mencoba memasukkan materi budi pekerti secara integrated learning ke dalam setiap mata pelajaran, namun belum efektif dan tidak maksimal, mengingat tidak semua guru mampu mampu mengaplikasikannya. Dengan demikian, pendidikan budi pekerti sangat penting menjadi mata pelajaran yang berdiri sendiri dalam kurikulum sekolah.

Dalam penelitian ini terdapat persamaan dan perbedaan dengan penelitian-penelitian sebelumya. Persamaan penelitian ini dengan penelitian sebelumnya yaitu, sama-sama menggunakan teori Sistem dan Strategi Kesopanan Model Scollon dan Scollon (2001:54-57). Penggunaan penelitian menggunakan teori ini masih belum banyak dipakai. Sedangkan perbedaannya yaitu terletak pada objek kajian yang digunakan. Penelitian yang pertama J. César Félix-Brasdefer (2006), objek Studi ini menyelidiki strategi linguistik yang digunakan oleh penutur asli laki-laki bahasa Spanyol Meksiko untuk menjaga keseimbangan hubungan interpersonal dalam interaksi penolakan dalam situasi formal dan informal. 
Penelitian kedua Majid Wahdi (2013), objek data dikumpulkan melalui dokumen tertulis seperti novel, terjemah Quran BJ, dan komunikasi antar keluarga atau masyarakat. Penelitian yang ketiga Robby Andre (2018), obyek kajiannya yaitu orang tua murid Tionghoa Surabaya di TBI (The British Institute) Surabaya serta refleksi budaya yang dapat dilihat dari penggunaan bahasa yang terjadi di komunitas tersebut. Penelitian keempat Azwan Universitas Iqra Buru (2018), objek penelitiannya yaitu strategi kesantunan penolakan yang digunakan oleh orang Ambon dalam menolak permintaan. Sedangkan dalam penelitian kali ini, objek penelitiannya adalah percakapan di WhatsApp group kelas 5 SDN Sumberbening 1, Kecamatan Bringin, Kabupaten Ngawi. Dengan perbedaan dan persamaan penelitian terdahulu dan penelitian ini, bisa memperjelas bahwa dalam penelitian ini merupakan suatu hal yang baru. Pemakaian teori Sistem dan Strategi Kesopanan Model Scollon dan Scollon (2001: 54-57) dalam meneliti Strategi Kesopanan Berbahasa di WhatsApp Group Kelas 5 SDN Sumberbening 1 Kabupaten Ngawi pada masa Pandemi Covid-19 sangat efektif.

Hasil penelitian ini selaras dengan hasil penelitian mengenai bentuk, nilai, dan fungsi kesantunan berbahasa Jawa dalam interaksi antara guru dan siswa ketika pembelajaran bahasa Jawa di SMP N 1 Banyumas yaitu mematuhi prinsip kesantunan berbahasa Jawa dan penggunaan unggahungguh basa yang terdiri dari ngoko realisasi dari solidarity dan krama realisasi dari independence dalam Taksonimi Scollon and Scollon (Rahadini \& Suwarna, 2014). Penelitian "Politeness Strategies of Refusals to Requests by Ambonese Community" menemukan hal sama dimana pada konteks komunikasi hirarkis dari lower ke higher menerapkan strategi independence dalam taksonomi kesopanan Scollon dan Scollon (Azwan, 2018).

Penelitian mengenai "Tingkat Tutur Bahasa Jawa dalam Film Kartini” menemukan bahwa faktor yang menguatkan pemilihan tingkat tutur adalah faktor power khususnya status sosial. Power umur dan distance dalam hal relasi kekerabatan tidak menjadi faktor pemilihan tingkat tutur (Rizky \& Puspitorini, 2019). Temuan ini tidak sepenuhnya sama dengan temuan penelitian ini.

Fenomena pemantuhan terhadap kesopanan semacam ini dimungkinkan terjadi karena di tengah menurunnya tatakrama terutama di kalangan anak muda, di tengah masyarakat masih ada peduli dengan malakukan kegiatan-kegiatan yang mendukung pelestarian kesopanan misalnya melalui "Pemberdayaan Ibu Rumah Tangga dalam Pembelajaran Unggah-Ungguh Bahasa Jawa sebuah Upaya Pendidikan Karakter Anak" (Alfiah et al., 2010).

\section{SIMPULAN}

Kesopanan berbahasa dalam komunikasi pembelajaran merupakan hal yang sangat penting. Apalagi di masa Pandemi seperti ini. Pembelajaran dilaksakanan secara online. Unggah-ungguh komunikasi harus tetap terjaga. Dalam penelitian ini, peneliti ingin meneliti sejauh mana penerapan strategi kesopanan berbahasa dapat dilaksanakan. Hasilnya penerapan strategi kesopanan berbahasa masih tetap dilaksanakan dengan baik. Karena berdasarkan penelitian, lebih dari 50\% komunikasi masih menerapkan strategi kesopanan berbahasa dengan baik. Pemakaian teori Sistem dan Strategi Kesopanan Model Scollon dan Scollon (2001: 54-57) dalam meneliti Penerapan Strategi Kesopanan Berbahasa di WhatsApp Group Kelas 5 SDN Sumberbening 1 Kabupaten Ngawi pada masa Pandemi Covid-19 sangat efektif.

\section{DAFTAR PUSTAKA}

Alfiah, A., Mukhlis, M., \& Kurniawati, Y. (2010). Pemberdayaan Ibu Rumah Tangga dalam Pembelajaran Unggah-Ungguh Bahasa Jawa sebuah Upaya Pendidikan Karakter Anak. EDimas: Jurnal Pengabdian Kepada Masyarakat, 1(2), 93-100. https://doi.org/10.26877/edimas.v1i2.146

Astiana Ajeng Rahadini, dkk. 2014. KESANTUNAN BERBAHASA DALAM INTERAKSI PEMBELAJARAN BAHASA JAWA DI SMP N 1 BANYUMAS. Jurnal LingTera, Volume 1 - Nomor 2

Azwan, A. (2018). POLITENESS STRATEGIES OF REFUSALS TO REQUESTS BY AMBONESE COMMUNITY. LINGUA : Jurnal Bahasa, Sastra, Dan Pengajarannya, 15(1), 1-6. https://doi.org/10.30957/lingua.v15i1.440 
Brown, P. And S. C. Levinson, 1987. Politeness: Some Universal in Language Usage. Cambridge: Cambridge University Press.

Eelen, G. (2001). A critique of politeness theories. Manchester: St. Jerome Publishing.

Erna Setyowati.(2009). Pendidikan Budi Pekerti Menjadi Mata Pelajaran di Sekolah.Lembaran Ilmu Kependidikan Jilid 39, No.2, Desember 2009.

Gunarwan, Asim. (2005). Beberapa prinsip dalam komunikasi verbal: Tinjauan Sosiolinguistik dan Pragmatik. Dalam Pranowo, dkk. (Eds.), Bahasa, Sastra, dan Pengajarannya (1-18). Yogyakarta: Sanata Dharma University Press.

Harjawiyana, Haryana \& Supriya. (2009). Marsudi unggah-ungguh basa Jawa. Yogyakarta: Kanisius.

Iskandarwassid dan Sunendar, Dadang. 2009. Strategi Pembelajaran Bahasa. Bandung: PT Remaja Rosdakarya.

J. César Félix-Brasdefer. 2006. Linguistic politeness in Mexico: Refusal strategiesamong male speakers of Mexican Spanish. Journal of Pragmatics 38 (2006) 2158-2187

Rahadini, A. A., \& Suwarna, S. (2014). KESANTUNAN BERBAHASA DALAM INTERAKSI PEMBELAJARAN BAHASA JAWA DI SMP N 1 BANYUMAS. LingTera, 1(2), 136-144. https://doi.org/10.21831/lt.v1i2.2591

Rian Damariswara. 2016. ANALISIS KETIDAKTEPATAN PENGGUNAAN BAHASA JAWA KRAMA ALUS MAHASISWA PGSD ANGKATAN 2012 UN PGRI KEDIRI DALAM MATA KULIAH BAHASA DAERAH. Jurnal Pendidikan Dasar Nusantara. Volume 2, Nomor 1

Rizky, N. A., \& Puspitorini, D. (2019). TINGKAT TUTUR BAHASA JAWA DALAM FILM KARTINI. Kawruh : Journal of Language Education, Literature and Local Culture, 1(2), 184-206. https://doi.org/10.32585/kawruh.v1i2.406

Robby Andre. 2018. Sistem Kesantunan serta Refleksi Budaya dari Komunitas Orang Tua Murid Tionghoa Surabaya di TBI Surabaya. Etnolingual Vol 2 No 1

Sasangka, Sry Satriya Tjatur Wisnu. 2005. Kamus Jawa- Indonesia Krama- Ngoko. Jakarta: Yayasan Paramalingua.

Scollon, R., \& Scollon, S. W. (2001). Intercultural Communication: A DiscourseApproach. UK: Basil Blackwell Ltd.

Suharti. 2006. Penerapan Unggah-Ungguh Berbahasa Jawa di Sekolah: Upaya Pembinaan Perilaku Bangsa yang Tangguh. Makalah KBJ IV. Semarang.

Sukarno. (2010). The reflection of Javanese cultural concepts in the politeness Javanese. ProQuest, $12,59-71$.

Suseno, Franz Magnis. 1985. Etika Jawa: Sebuah Analisa Falsafati tentang Kebijaksanaan Hidup Jawa. Jakarta:PT Gramedia.

Wadji, Majid. 2013. Sistem Kesantunan Masyarakat Tutur Jawa. Linguistika : Buletin Ilmiah Program Magister Linguistik Universitas Udayana, Volume 20.

Wardhaugh, R. (1986). An Introduction to Sociolinguistics. Cambridge: Blackwell Publisher.

Website Andi.Link. Website Hootsuite (We Are Social): Indonesian Digital Report 2019. (Online), (https://andi.link/hootsuite-we-are-social-indonesian-digital-report-2019/, diunduh 20

September 2021). 